\title{
Camiseta e comunicação: reflexões sobre a indumentária nas indústrias culturais
}

\author{
T-shirt and communication: reflections \\ on the garment in the cultural industries
}

por Gabriel Baquit

RESUMO

A camiseta é uma das vestimentas mais simples e universais encontradas em um guarda-roupa. Originalmente utilizada como roupa íntima, essa peça de vestuário popularizou-se entre os jovens na década de 1950 e tornou-se símbolo da rebeldia de uma geração crescida no pós-guerra. 0 presente artigo tem como objetivo estudar, a partir de uma pesquisa bibliográfica, o processo histórico de popularização da camiseta, propondo algumas reflexões sobre as propriedades de comunicação dessa indumentária. Ao longo do estudo, reconhecemos as evoluções dessa vestimenta e suas relações com as indústrias culturais, até transformar-se em um meio de comunicação. A camiseta já foi sinônimo de protesto, e mostrou-se uma mídia alternativa eficaz para diversos fins. Por seguir as lógicas da sociedade de consumo, entretanto, seu discurso perdeu impacto, e sua utilização passou a ser uma questão de aparência mais do que uma expressão de ideais.

Palavras-chave camiseta; comunicação; mídia; consumo; indústrias culturais

\begin{abstract}
The t-shirt is one of the simplest and most universal clothes found in a wardrobe. Originally used as underwear, this apparel has become popular among youth in the 1950 s and came to be a symbol of rebellion for a generation grown in the postwar period. This paper aims to study, from a literature review, the historical process of popularization of the t-shirt, suggesting some reflections on the communication properties of this garment. Throughout the study, we recognize that evolutions of this clothing and its relations to the cultural industries, until it became a communication medium. The t-shirt has been related to protest, and had shown to be an effective alternative media for various purposes. By following the logics of consumer society, however, its discourse has lost impact, and its usage has become a matter of appearance rather than an expression of ideals.
\end{abstract}

Keywords t-shirt; communication; media; consumption; cultural industries 


\section{Surgimento e popularização}

Mapear a história do surgimento e popularização da camiseta não é uma atividade tão exata quanto se parece. Ora usada como peça íntima, ora como peça exposta, a camiseta como conhecemos tem um trajeto incerto devido à falta de registros históricos precisos e à presença de pontos de vista paralelos que apresentam versões distintas para um mesmo fato. Não há dúvidas, entretanto, sobre sua primeira utilização, que foi como roupa íntima.

À Idade Média, camisolões de um tecido duro e não aderente ao corpo eram usados como roupa íntima. Essas roupas não eram retiradas nem na hora do banho, pois o contato com o próprio corpo nu era considerado pecaminoso (LOPES, 2005). Por volta do século XVI, o homem passou a usar calças, e os camisolões precisaram ser encurtados. Com formato semelhante ao das camisetas que conhecemos, mas servindo de roupa íntima, a undershirt, além de proteger das mudanças de temperatura, também absorvia a transpiração do corpo, evitando o desgaste da camisa - esta sim, usada como roupa à mostra.

Algumas hipóteses tentam explicar como uma peça íntima passou a ser utilizada publicamente. Uma das versões indica que, por volta de 1880, a undershirt fazia parte do uniforme da Marinha Norte-Americana. Usada corretamente sob o uniforme, essa indumentária era produzida de flanela branca. Quando os navios partiam, os marinheiros, que executavam trabalhos braçais pesados, se despiam do fardamento desconfortável, adotando a undershirt como única proteção em seus torsos (EASBY; OLIVER, 2007).

Barros (1988) identifica outra versão histórica, que destaca a adaptação dos colonizadores europeus aos climas tropicais dos países que exploravam. Segundo o autor, os colonizadores improvisaram diante do clima tropical, se desprovendo dos trajes pesados e exibindo as camisolas brancas que usavam como roupas de baixo.

Há, ainda, registros em pinturas e esculturas desde o Renascimento que apresentam figuras masculinas vestindo peças de roupa que muito se assemelham às camisetas atuais. A escultura Escravo Moribundo, concluída por Michelangelo em 1516, mostra um rapaz seminu vestindo apenas uma camiseta sem mangas. Quadros como No Barco, de Édouard Manet (1874), 0 Almoço dos Remadores, de Pierre-Auguste Renoir (1881) e 0 Lavrador de Café, de Cândido Portinari (1939) também são exemplos de obras que registram artisticamente a utilização da camiseta na história.

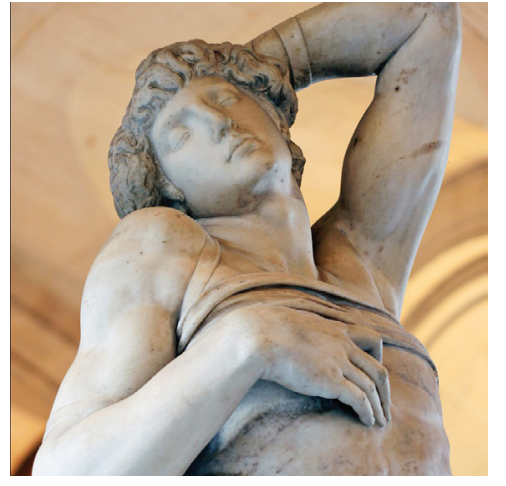

Figura 1. Detalhe da escultura Escravo Moribundo, Michelangelo, 1516. Fonte: http://escultura-mundi.blogspot.com/. Acesso em 1. ago. 2012 


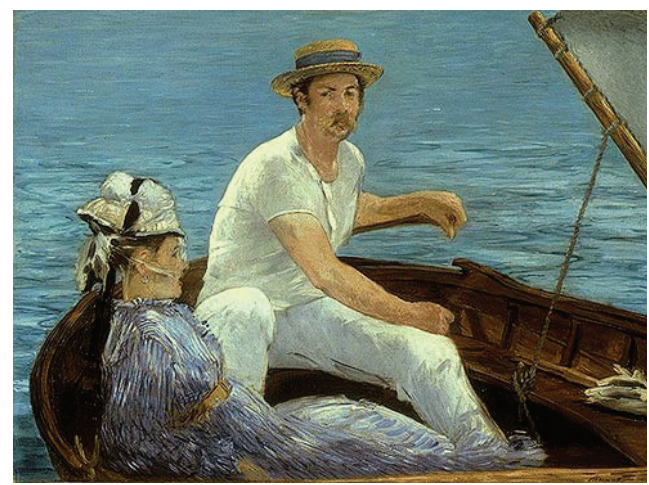

Figura 2. No Barco, Édouard Manet, 1974. Fonte: http://anasonarte.blogspot.com/.

Acesso em 1. ago. 2012

No Brasil, ao final do século XIX, o uso da undershirt se difundiu aos poucos nas praias do Rio de Janeiro. A peça era mais confortável do que as roupas de banho da época, compostas por largas camisas e shorts compridos. Segundo Lopes (2005), essa apropriação da peça como roupa de banho representou, à época, uma experiência de liberdade sem precedentes.

Qualquer que tenha sido a versão original, em um ponto todas convergem: "é a necessidade que dita o uso, não uma nova concepção de vida, expressa na maneira de se vestir, o que definiria um estilo" (BARROS, 1988, p.55). Até então, a camiseta só era utilizada como roupa à mostra em trabalhos braçais ou em situações nas quais era necessário um maior conforto e liberdade de movimentos.

0 comportamento dos consumidores de undershirt só mudaria na década de 30, graças a uma cena do filme Aconteceu Naquela Noite (It Happened One Night, 1934), de Frank Capra. Na cena em questão, o personagem de Clark Gable se despia: tirava o paletó, a gravata e, por fim, a camisa. Para a surpresa do público, o ator não estava em posse de uma undershirt, ao contrário do costume típico na América do Norte àquela época. As mulheres adoraram a visão do peitoral masculino exposto, e os homens seguiram a sugestão. Foi o bastante para a peça ser abolida dos costumes da população por alguns anos (EASBY; OLIVER, 2007).

Durante a Segunda Guerra Mundial, a camiseta foi adotada como uniforme pelos soldados norte-americanos. Como meio de identificar seus postos, os soldados passaram a estampar informações nas camisetas por meio de stencil'. A cobertura da guerra pela mídia deu visibilidade à vestimenta, estabelecendo-a como símbolo de masculinidade e força, sendo, ao mesmo tempo, confortável e versátil.

0 grande momento da camiseta, porém, ainda não havia chegado. Marlon Brando, no filme de Elia Kazan intitulado Uma Rua Chamada Pecado (A Streetcar Named Desire, 1951), deu início à popularização da peça de roupa. 0 ator aparece com uma camiseta branca ajustada ao seu tórax e braços, criando o primeiro modelo de galã moderno. Dois anos mais tarde, Marlon Brando repetiria o visual jeans-e-camiseta na produção 0 Selvagem (The Wild One, 1953), de Laslo Benedek. Mas 0

1 Técnica de impressão por meio de moldes e tinta em spray. 
verdadeiro herói de toda uma geração ainda estava por surgir. Em meio a porte de arma de fogo e menores consumindo bebidas alcoólicas, se desenvolve a trama de Juventude Transviada (Rebel Without A Cause, 1955), de Nicholas Ray. 0 filme estreou apenas três semanas após a morte do ator que elevaria ao posto de mito: James Dean.

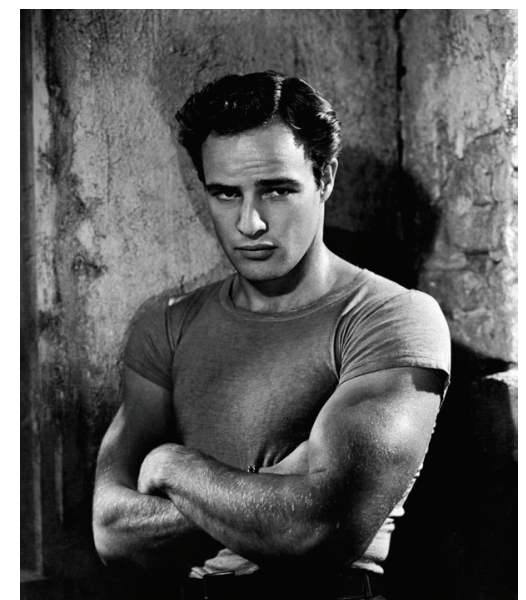

Figura 3. Marlon Brando em Uma

Rua Chamada Pecado, de Elia Kazan, 1951. Fonte: http://doctormacro.com/. Acesso em 1. ago. 2012

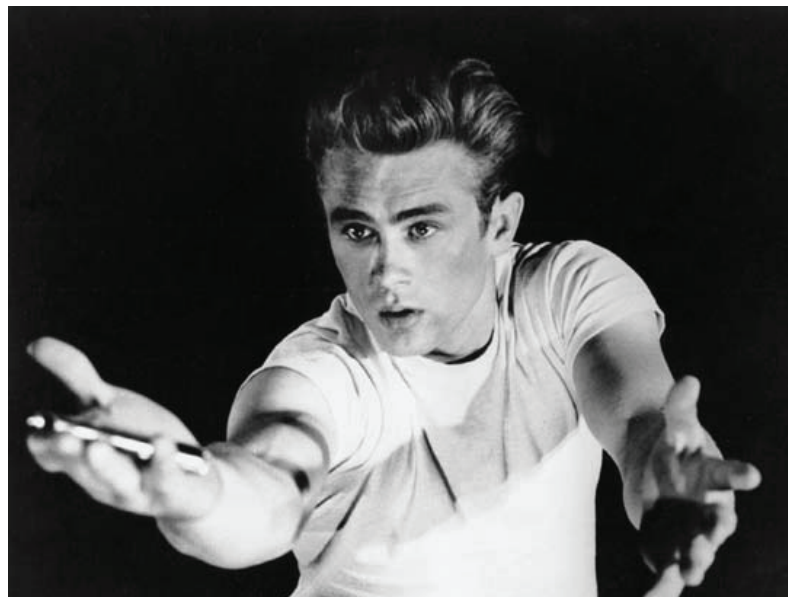

Figura 4. James Dean em Juventude Transviada, de Nicholas Ray, 1955. Fonte: http://doctormacro. com/. Acesso em 1. ago. 2012

Talvez por toda a repercussão que a morte de James Dean gerou à época, e por acabar com os sonhos de milhares de fãs sedentos por um ídolo que representasse os anseios dessa juventude transviada crescida no pós-guerra, os modos de seu personagem - principalmente a maneira de vestir - foram reproduzidos quase que em série. 0 ator transformou a camiseta no símbolo da nova geração que surgia, "num emblema dos garotos indóceis e indomáveis do pós-guerra" (AUGUSTO, 1988, p.110).

Os adolescentes já não eram considerados adultos jovens ou versões menores de seus pais, eles eram o retrato da nova juventude americana. Dirigiam motocicletas, escutavam rock'n'roll e lutavam em busca de seu lugar na pacata sociedade suburbana recém-instaurada. 0 s anos 60 se aproximavam à medida que a camiseta ganhava seu espaço, não mais exposta em seções de roupas íntimas, mas sim como uma peça de roupa à mostra, produzida para ser mais durável. Inscrições de protestos passaram a estampar os seus tecidos. À entrada dos anos 70 a peça se difundiu em maior escala como unissex, ampliando seu mercado consumidor.

Conscientes deste novo e promissor mercado que se consolidava, produtos específicos para jovens foram criados, e eles passaram a ter sua própria moda. 0 mercado e a indústria estavam, agora, prontos para atender às necessidades de consumo dos filhos do baby-boom. 0 estilista Yves Saint Laurent declarou, à época, que "tudo o que uma garota de 20 anos precisa é de uma t-shirt e um par de jeans" (apud LOPES, 2005). A camiseta foi reinventada a partir de técnicas de impressão 


\section{Camiseta e comunicação: reflexões sobre a indumentária nas indústrias culturais}

em serigrafia e de utilização de tintas spray, que estamparam na sua superfície, outrora lisa, mensagens com uma visibilidade que não se podia imaginar. A liberdade de expressão tão estimada pela juventude finalmente ganhava asas.

Os anos 90 se aproximavam e traziam consigo uma grande revolução tecnológica prestes a explodir. A camiseta também acompanhou essa revolução, e alterações foram feitas em seus formatos, ajustes e, principalmente, em seus materiais. De tecidos sintéticos a peças feitas de sacos plásticos, tudo era válido no democrático mercado da camiseta, que deixava de ser uma simples peça de roupa para se tornar, também, um meio de comunicação.

Crane (2006) acredita que a camiseta assumiu a função desempenhada pelo chapéu até 0 início do século XX: identificar instantaneamente a posição social do indivíduo. Mas, enquanto o chapéu sinalizava o status de classe social, a camiseta expressa o status ideológico; fala sobre ideologia, diferença e mito.

É certo que a peça perdura até os dias de hoje e mantém-se contemporânea, vestindo a juventude geração a geração. Barros (1988) associa essa peculiaridade da camiseta à sua simplicidade, objetividade e funcionalidade. Mais do que acompanhar modismos, ela paira sobre a moda e se distingue das demais peças de roupa. Comparada à minissaia, roupa que também tem a trajetória ligada à rebeldia, a camiseta consegue ser eterna, "não navega ao sabor das tendências e, graças a isso, não vai e volta à moda tal como uma onda no mar" (BARROS, 1988, p.53). Todas essas virtudes somam à camiseta motivos os quais fazem com que a peça se finque com firmeza na moda, um território habitado e regido pela efemeridade.

\section{Estampa, comunicação e mídia}

Por volta de 1895, surgia, nos Estados Unidos, uma série de histórias em quadrinhos chamada The Yellow Kid. A personagem dessas histórias - um garoto careca, de oreIhas grandes e que vestia um camisolão amarelo - em vez de se comunicar por baIões de texto ou tarjas, expressava-se por meio de frases inscritas em seu camisolão. 0 Yellow Kid foi, portanto, o precursor na comunicação verbal por meio da camiseta.

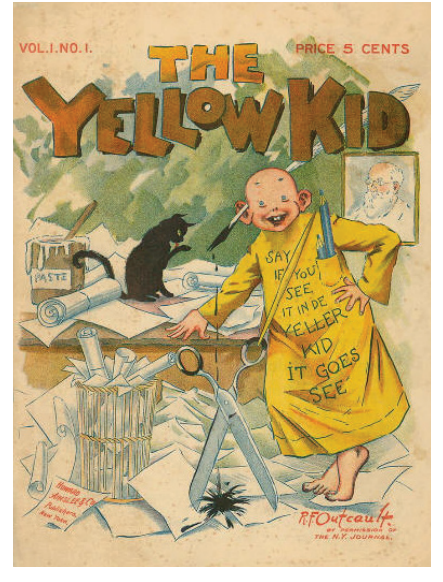

Figura 5. Capa da primeira edição de The Yellow Kid, 1897. Fonte: http:// philsp.com/. Acesso em 1. ago. 2012 
Em meados do século XIX, a impressão de dizeres em camisas surgiu como meio de identificar seus usuários a uma organização, como um time esportivo, sendo adotada, também, na década de 30, por algumas universidades. 0 uso da camiseta como suporte de divulgação de outros tipos de informação é identificado a partir da década de 40, quando slogans e rostos de políticos passaram a estampar essa peça de roupa. Thomas E. Dewey, candidato à presidência dos Estados Unidos em 1948, parece ter sido o primeiro a usar a camiseta para fins políticos e publicitários, com peças que estampavam as inscrições Dew it with Dewey no peito.

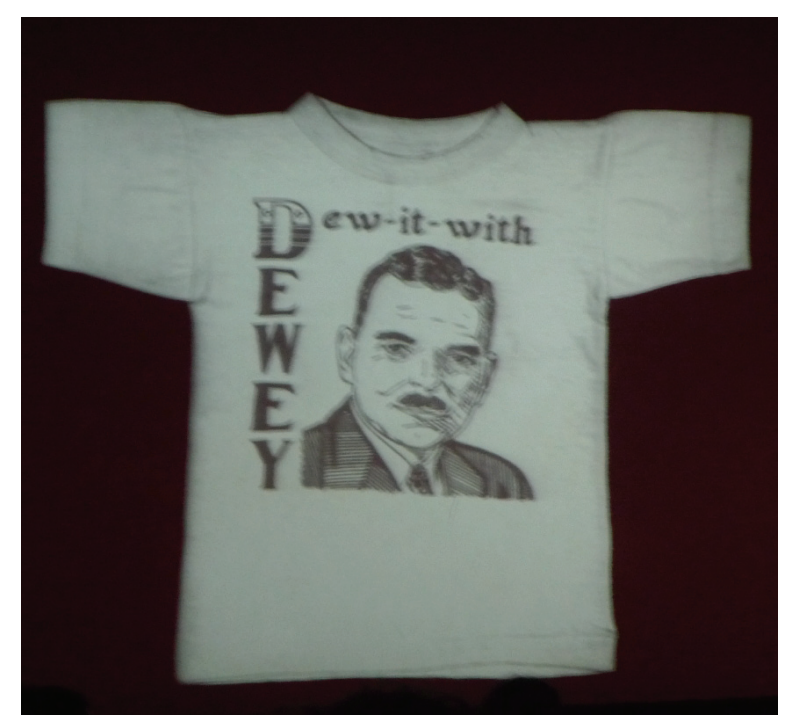

Figura 6. Camiseta do candidato Thomas E. Dewey. Fonte: http:// moyatees.wordpress.com/.

Acesso em 1. ago. 2012

Durante os anos 50, nosso objeto de estudo foi elevado a ícone de rebeldia e revolta. Mas foi somente na década seguinte que esse caráter tornou-se explícito, quando uma simples peça de roupa se transformou em um meio de comunicação de massa (MACIEL, 1988). A descoberta das possibilidades de utilização da camiseta como meio de comunicação foi espontânea e intuitiva e não demorou muito a se proliferar.

Grupos de contracultura não tinham o suporte da grande mídia, e perceberam 0 impacto que suas mensagens alcançavam quando eram estampadas em camisetas. Passaram, então, a fazê-lo com maior frequência, estampando no peito seus ideais e mostrando a todo o mundo seus modos de pensar.

0 movimento hippie, manifestando-se contra a violência, a guerra e demais sintomas do sistema capitalista em vigor, adotou um visual paz e amor, recusando a moda então difundida, adotando sua própria maneira de vestir: pobre, simples e criativa, desenhando suas próprias estampas e tingindo suas camisetas à mão. Na década de 70, o movimento punk também adotou a camiseta como uniforme. Seus meios de expressão nessas vestimentas incluíam, além de estampas, rasgos e intervenções com alfinetes e costuras, simulando cicatrizes na pele.

A indústria cultural$^{2}$, identificando esses comportamentos diferentes e contesta-

2 Entende-se por indústria cultural o processo de industrialização da cultura, a sua transformação $\rightarrow$ 
dores, apropriou-se dos visuais dos movimentos de contracultura e os instituiu como mercadoria. "Se multidões de jovens se vestiam daquela forma, [...] eis aí um novo, dinâmico e universal mercado. Uma maneira nova de se vestir significa uma nova maneira de comprar" (JAPIASSU, 1988, p.84).

Após os hippies e os punks, foram os yuppies - jovens ricos e profundamente comprometidos com o consumo - que adotaram a camiseta como vestimenta. Para os yuppies, porém, as mensagens a comunicar eram outras, e a vontade de mostrarem ao mundo que pertenciam a classes sociais mais abastadas prevaleceu. Assim, as camisetas deixaram de ser as peças mais simples de um guarda-roupa e passaram a ostentar as marcas de seus fabricantes em letras garrafais (LOPES, 2005).

Na camiseta, a indústria da propaganda também acabou por descobrir um novo e versátil suporte para mensagens publicitárias, com a vantagem de servir como meio e mensagem. Ao mesmo tempo em que é mercadoria, a camiseta é divulgação. Por que pagar a um homem-sanduíche para fazer divulgação de uma marca se há a possibilidade de distribuir camisetas publicitárias como brindes - ou até mesmo vendê-las? Vestindo a camiseta, o consumidor torna-se modelo da marca que exibe e de seus ideais, disseminando-os por onde passa.

Japiassu (1988) reconhece a utilização de camisetas em uma estratégia publicitária da empresa General Eletric como pioneira no Brasil: a empresa patrocinou uma torcida organizada na Copa do Mundo de 1962, no Chile. Uma caravana vestida com camisetas promocionais viajou para o evento, chamando muita atenção da mídia. A estratégia parece ter dado certo, sendo adotada posteriormente pelas Lojas Ducal na Copa de 66 e, mais recentemente, pela Brahma, na Copa de 94.

Outro caso de estratégia de marketing envolvendo a utilização de camisetas foi recentemente desenvolvido pela marca Coca-Cola. A empresa, que atua no mercado de bebidas, lançou-se, também, no mercado da moda. Primeiramente, em parceria com a marca de roupas Colcci, foi lançada uma coleção que homenageava e exibia a marca Coca-Cola em camisetas destinadas ao público jovem. Inspirando-se nos ideais do movimento Pop Art, a marca desejou se perpetuar como objeto de desejo e ícone de diversas gerações. Alguns anos depois, foi lançada no mercado uma marca própria, a Coca-Cola Clothing, seguindo o mesmo padrão de vestimentas exibindo produtos Coca-Cola. Ao passo em que é mercadoria, o produto serve, também, como forma de divulgação.

Seguindo o sucesso como item de merchandising desde grandes empresas a comércios de vizinhança, a camiseta não demorou a entrar no mercado fonográfico, exibindo nomes, rostos e capas de discos, tornando-se uma das principais fontes de lucro das bandas de rock nos anos 70 (EASBY; OLIVER, 2007). 0 primeiro caso

$\rightarrow$ em objeto de consumo e destituição do seu valor original (ADORNO; HORKHEIMER apud STRINATI, 1999). Neste contexto, a indústria cultural pode ser representada pelas mídias (jornais, revistas, rádio e televisão), pela publicidade e pelas indústrias fonográfica e cinematográfica. 
identificado de astro do rock'n'roll comercializando esses souvenirs, foi o de Elvis Presley, em 56. Os jovens do The Beatles seguiram o exemplo em 64, mas Easby e Oliver conferem ao grupo The Monkees a primeira estratégia de merchandising bem sucedida de uma banda de rock, em 1967.

Na política brasileira, a camiseta teve um papel crucial durante a campanha das Diretas Já, em meados da década de 80 . Embora organizada pelos próprios políticos, a campanha ultrapassou limites e contagiou a população brasileira, levando multidões às ruas. A palavra de ordem do movimento sofreu, inicialmente, um boicote por parte da mídia tradicional. Foi preciso o movimento tornar-se quase uma unanimidade nacional para que os meios eletrônicos aderissem.

Enquanto a comunicação era velada, o boca-a-boca tinha mídia limitada como suporte, elevando, assim, a camiseta a um meio de comunicação de massa:

Na medida em que o movimento utiliza de recursos como esse, consegue ultrapassar o bloqueio e sair da clandestinidade, multiplica-se, ganha repercussão e acesso aos media eletrônicos. Sua utilização ampla, no caso, supriu a falta de jornais e tevês, conduziu a palavra de ordem ao dia-a-dia, a todos os lugares. A camiseta serviu de cimento social, de multiplicador, e arrastou os outros media atrás dela. (MACIEL, 1988, p.69)

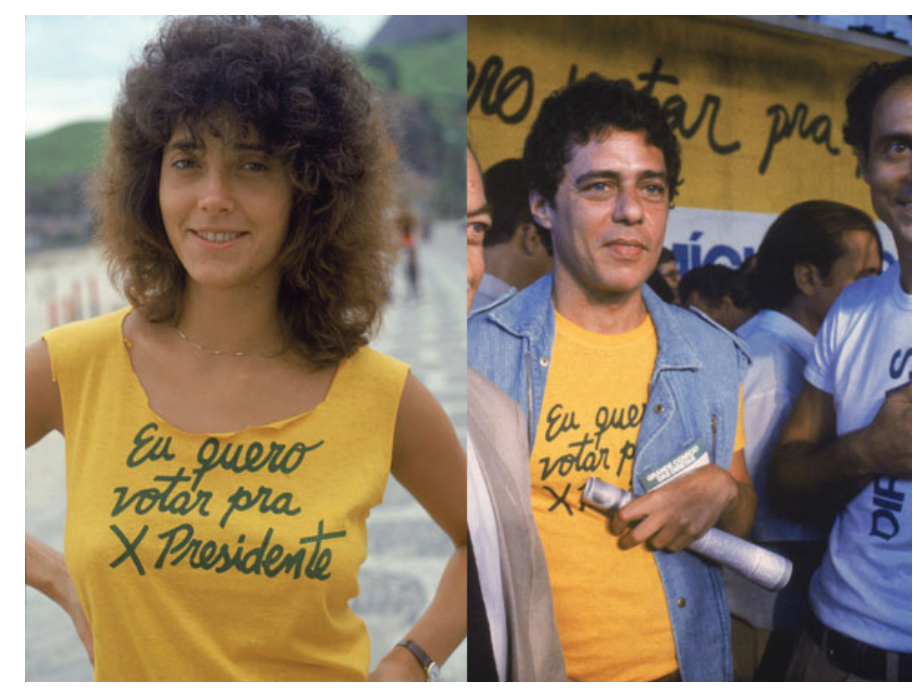

Figura 7. A atriz Christiane Torloni e o cantor e compositor Chico Buarque vestindo camisetas da campanha Diretas Já. Fonte: http://muitasoutras.blogspot.com/. Acesso em 1. ago. 2012

Outro exemplo da utilização da camiseta no cenário político brasileiro foi protagonizado por Fernando Collor de Mello. 0 então presidente, no início da década de 90 , adotava hábitos saudáveis ao praticar seu cooper pela manhã. Por ser figura públi$\mathrm{ca}$, tornava-se alvo de fotógrafos durante suas saídas, e passou a vestir camisetas com dizeres que intrigavam a mídia e o público. Frases como "Roxo de paixão pelo 
Brasil", "Deixe meu ozônio livre" e "Não fale em crise, trabalhe" eram estampadas primeiramente nas camisetas do político para, posteriormente, estamparem as páginas dos jornais. Collor "fazia, dessa maneira, do próprio peito um cartaz e passava recados através de uma imagem elaborada pelos marqueteiros" (JORGE, 2006).

A camiseta estampada popularizou-se, ganhou visibilidade nas ruas e incumbiu-se de funções para além do vestir. A prática de interação do sujeito com o ambiente que 0 circunda foi revolucionada. 0 indivíduo tornou-se agente modificador do espaço que habita à medida que procura novas formas de comunicar e interagir em sociedade.

\section{Discursos do consumo}

As possibilidades se expandiram para atender aos mais variados estilos de vida. A pluralidade cultural e a grande diversidade de pontos de vista são valorizadas e expostas nas ruas por meio de imagens, grafismos, textos, ilustrações e diversas composições visuais estampadas na superfície têxtil das camisetas.

Segundo o dicionário Aurélio (1975), o significado de estampar é algo como imprimir letras, dísticos ou figuras por meio de moldes, obtendo-se cópias sucessivas e isoladas. Mas, ainda na mesma fonte, também encontramos outros sentidos que podem ser adquiridos pela palavra, como: assinalar, deixar vestígio, trazer à tona, tornar óbvio, mostrar e exibir. Podemos dizer, então, que quem veste uma camiseta estampada está estampando a si mesmo, ou seja, está se mostrando, se exibindo, deixando seus vestígios, trazendo à tona o que está dentro de si.

Foi assim com os hippies, por exemplo. Para o movimento hippie não bastava adotar posturas que condiziam com seus ideais. Mais do que isso: era necessário mostrar. E assim seguiu com os punks, os yuppies e os manifestantes das mais diversas causas. Easby e Oliver (2007) concordam que a popularidade das camisetas estampadas está relacionada à necessidade que o indivíduo tem de mostrar sua admiração por algo. Freitas explica esse fenômeno quando aponta que:

A pós-modernidade se agita na evolução de um imaginário no qual os objetos se exibem em hiperespetáculos, festivais cotidianos de artifícios das diversas esferas dos espaços privados e semi-públicos. Vive-se um dia-a- dia invadido pelos argumentos de cada tribo, seja enquanto negação ou afirmação de valores transnacionais ou locais, seja pelo simples prazer de estar junto. (FREITAS, 2005 apud MORAIS, 2006, p.9)

A necessidade do mostrar ultrapassa o caráter identitário e a auto-afirmação. 0s dizeres ou as imagens impressas nas camisetas tomam, assim, um viés imperativo-afirmativo, que faz com que o indivíduo sinta-se relevante ao tornar-se enunciador. 0 consumidor não quer somente consumir, mas quer ser consumido, afinal, ele também é um produto (BAUMAN, 2008). Assim, gera conteúdo pelo vestir, e o exibe, tornando-se figura pública por meio de seu discurso aberto. 
Bauman (2008) acredita que, na modernidade, o indivíduo quer ser visto, notado, comentado e desejado por muitos, e isso é perceptível nas intenções de um transeunte estampado. Bergamo (2007) dá continuidade ao raciocínio quando propõe que:

[Na moda] estão depositados valores, crenças, expectativas, interesses, ilusões, sonhos, experiências. E quando tudo isso encontra condições materiais próprias, passa a adquirir força de realidade, a aglutinar pessoas que compartilham as mesmas expectativas e os mesmos interesses, a fazer valer a crença na realidade de cada uma dessas coisas. (BERGAMO, 2007, p.216-7)

0 autor atenta para a propriedade que a moda e, no caso, a camiseta têm de incumbir papéis, de distribuir scripts a serem interpretados num espetáculo cotidiano, dependendo do compartilhamento de interesses dentre os indivíduos envolvidos. 0 campo da moda é uma tensão constante entre valores, crenças e expectativas que ali se tornam possiveis e ganham uma forma de expressão e uma possibilidade de realização (BERGAMO, 2007).

A manifestação de valores e ideais por meio da vestimenta expõe simbolicamente a posição ideológica e o status que se quer manter e ocupar na estrutura social, de acordo com os valores de certa tribo. Essa posição e esse status ganham expressão por associações a estilos de vida fabricados e difundidos pela publicidade e pelas indústrias culturais. "Numa época automatizada, cada vez mais carente de heroísmo, as camisetas e seus slogans proclamam valores como a liberdade e os direitos. E valem também, por si mesmas, como fetiches" (MUGGIATI, 1988, p.135).

Easby e Oliver (2007) sentem uma massificação e superexposição de pontos de vista e ideologias por meio da camiseta, e sugerem um possível esvaziamento de significância dessa vestimenta na contemporaneidade. Quem veste uma camiseta nem sempre veste o que é, acabando por destituir, desta forma, a estampa do seu sentido. Os autores se fazem entender pelo seguinte exemplo: “A Paris Hilton realmente ouve Ramones? Ela tem um álbum favorito do Rolling Stones? Provavelmente não, mas pegue qualquer revista e você poderá vê-la vestindo uma camiseta dessas bandas mesmo assim" (EASBY; OLIVER, 2007, p.7, livre tradução). Eles não se posicionam a favor ou contra essa produção em massa de camisetas de bandas que, há algumas décadas, eram produzidas em tiragens limitadas para venda dentro dos próprios shows. Enquanto, por um lado, se pagaria centenas de dólares para comprar um item antigo e raro de colecionador, por outro, pode-se encontrar facilmente um substituto manufaturado por menos de dez dólares.

A passagem de souvenir de caráter semi-exclusivo a um produto vastamente comercializado em lojas de departamento se insere na crítica de Benjamin (apud STRINATI, 1999) à Escola de Frankfurt sobre o status da obra de arte em sua reprodutibilidade técnica. Enquanto, para Adorno, a reprodução é vista como algo negativo, Benjamin acredita que sua reprodução a torna mais acessivel ao grande público, que seu valor ritualístico é substituído pelo seu valor de exibição. A postura de Benjamin enfatiza o potencial democrático e participativo da reprodutibilidade sobre 0 autoritarismo e a repressão da unicidade. 
A vasta reprodução de estampas de camisetas pode ser reconhecida no movimento Pop Art, que zombava da banalização da mercadoria e criticava o consumo desenfreado e destituído de sentido. 0 movimento artístico, que baseava-se na ironia para elevar objetos de consumo ao patamar de obras de arte, também traçou o caminho inverso, difundindo a ostentação da arte estampando-a em camisetas. A Pop Art zombava de personalidades em evidência e de produtos produzidos em larga escala ao mesmo tempo em que os exaltava, e era exatamente nesse ponto que residia o seu caráter irônico.

Easby e Oliver (2007) sugerem uma contradição na camiseta: ela virou um ícone a tal ponto que utilizar uma camiseta estampada se trata mais de estilo do que de admiração. Podemos estender o conceito a camisetas de vários temas, como, por exemplo, causas sociais: quem veste uma camiseta estampada com o logotipo do Greenpeace não mantém necessariamente hábitos condizentes à preservação da natureza. Joffily (1988) defende esse pensamento quando alega que:

Se a camiseta, nos anos 60, descia as ruas na correnteza do protesto contra a guerra do Vietnã; subia aos céus junto com as estrelas do rock; tocava a eternidade carregada no rastilho dos mártires da contestação; sonhava um paraíso de paz e amor - se o vestir uma camiseta, naquela época, implicava uma postura crítica e militante, hoje, esse mesmo gesto é tão trivial (e contemporâneo) quanto jantar sozinho, em casa, diante da televisão ligada. (JOFFILY, 1988, p.11)

Outro exemplo da desapropriação de sentido da peça é reconhecido por Lima (1988). A autora afirma que é possivel observar nas ruas do Brasil transeuntes que vestem camisetas estampadas com expressões em línguas estrangeiras, mas que desconhecem o significado das próprias mensagens que estão transmitindo. Ela atribui o ato à necessidade que o usuário tem de, por meio da falsa, mas aparente, intimidade com a língua estrangeira, afirmar ser integrado a uma comunidade mais abastada.

Quando um consumidor se prende mais à estética da camiseta do que à idéia que ela passa ou à frase estampada - muitas vezes em outro idioma - ocorre um ruído na comunicação. Por não entender do que se trata a estampa que exibe, o usuário supõe que seus semelhantes - aqueles cuja opinião e julgamento realmente importam também não entenderão. 0 ruído na comunicação por meio da vestimenta já foi objeto de estudo de Eco (1989), quando o autor sugeriu a seguinte situação:

Se participo no conselho de administração de boina basca com estrela e barba à Guevara, de capote militar e sapatos de tênis, será muito difícil demonstrar aos presentes que as minhas intenções não eram polêmicas $e$ que me vesti assim por puro acaso. (ECO, 1989, p.18)

Eco sugere que, dependendo de onde estamos e de a quem nos apresentamos, um conjunto de roupas pode adquirir conotações diversas. No caso da camiseta, o que estampamos também pode ser interpretado equivocadamente, pois "o código é freqüentemente reconstruído no momento, na situação dada, sendo inferido a partir das próprias mensagens" (ECO, 1989, p.18). 
Para Maffesoli (2004), em qualquer forma de comunicação há a possibilidade de criação de um totem; um objeto que atrai o próximo e permeia a socialização dos indivíduos, desencadeando a formação de tribos. Diferentes tribos têm suas diferentes referências, que servem como indicadores de possíveis afinidades. "A comunicação, portanto, é forma contemporânea de exprimir essa velha forma arquetípica de comunhão em torno de um totem" (MAFFESOLI, 2004, p.24).

A estampa de uma camiseta, convertida em totem, participa no processo de representação da identidade de quem a veste e interfere em sua socialização, facilitando sua identificação com tribos que partilham dos mesmos interesses a partir, por exemplo, do tipo de mensagem que uma estampa exibe. A vida social baseia-se na atração e na repulsão, vibrando-se em comunicação com alguns, e não com outros; costurando-se o tecido social a partir das relações de empatia (MAFFESOLI, 2004).

\section{Considerações finais}

A camiseta surgiu como uma peça de roupa coadjuvante, com a função de proteger o corpo das variações climáticas ao mesmo tempo em que evitava que a roupa à mostra entrasse em contato com a transpiração. Diversos fatores fizeram com que essa indumentária evoluísse e conquistasse o gosto dos consumidores. A indústria cultural, por exemplo, - e principalmente o cinema - foi responsável pela popularização do uso da camiseta entre os jovens na década de 50, transformando-a em uma das peças mais universais, comumente encontradas nos guarda-roupas até hoje.

Movimentos de contracultura passaram a vesti-la como forma de protesto, elevando-a ao posto de meio de comunicação, o que chamou a atenção para sua utilização como mídia. Na propaganda, a camiseta mostrou-se versátil ao cumprir seu papel publicitário em diferentes contextos, satisfazendo as necessidades de vários tipos anunciantes. $\mathrm{Na}$ política, fez-se presente quando a mídia tradicional mostrou-se ineficaz: fortaleceu 0 boca-a-boca e aglutinou eleitores no desejo uníssono das Diretas fá.

De roupa-manifesto, porém, a camiseta foi destituída de seu significado e transformou-se em uma peça de uso trivial, enfraquecendo o seu sentido militante. A utilização de estampas relacionadas a causas e ideais tornou-se mais uma forma de espetáculo do que uma manifestação com fins maiores do que a exibição em si. Uma estampa nem sempre condiz com os hábitos adotados por quem a exibe, e isso enfraquece o seu discurso.

A camiseta rebela-se, protesta, divulga, critica, une, vende e engana. Como um papel em branco, sua natureza é livre e favorece uma comunicação eclética: "nela, tudo pode ser escrito, tudo pode ser estampado" (JOFFILY, 1988, p.12). A mensagem carregada pela estampa participa na comunicação do indivíduo com o mundo exterior, interferindo em seu processo de socialização. Ao vestirmos uma camiseta, portanto, estampamos a nós mesmos; conversamos em silêncio; ou simplesmente comunicamos por comunicar. 


\section{Referências bibliográficas}

> AUGUSTO, S. A estrela rebelde e sedutora. In: Joffily, R. (Ed.). A História da Camiseta. Rio de Janeiro: Marprint, 1988. p. 98-115.

> AURÉLIO. Novo dicionário da língua portuguesa. Rio de Janeiro: Nova Fronteira, 1975.

> BARROS, F. Fascinante evolução. In: Joffily, R. (Ed.). A História da Camiseta. Rio de Janeiro: Marprint, 1988. p. 51-60.

> BAUMAN, Z. Vida para consumo: a transformação das pessoas em mercadorias. Rio de Janeiro: Jorge Zahar Ed., 2008.

> BERGAMO, A. A experiência do status: roupa e moda na trama social. São Paulo: Editora UNESP, 2007.

> CRANE, D. A moda e seu papel social: classe, gênero e identidade das roupas. São Paulo: Editora Senac São Paulo, 2006.

> EASBY, A.; OLIVER, H. The Art of the Band T-shirt. London: Simon at Schuster, 2007.

$>$ ECO, U. 0 hábito fala pelo monge. In: Psicologia do Vestir. 3.ed. Lisboa: Assírio e Alvim, 1989, p. 3-20.

$>$ JAPIASSU, C. Outdoors em movimento. In: Joffily, R. (Ed.). A História da Camiseta. Rio de Janeiro: Marprint, 1988. p. 80-89.

> JOFFILY, R. Um personagem que faz história. In: Joffily, R. (Ed.). A História da Camiseta. Rio de Janeiro: Marprint, 1988. p. 9-22.

> LIMA, V. A. Uma visão comportamental. In: Joffily, R. (Ed.). A História da Camiseta. Rio de Janeiro: Marprint, 1988. p. 42-49.

> JORGE, T. M. 0 mito político em imagens de campanha. Revista/ Site MídiactPolítica. Brasília, 01 mai. 2006.

> LOPES, J. Cada um na sua. Super Interessante, v. 212, abr. 2005. Disponível em: <http:// super.abril.com.br/superarquivo/2005/conteudo_376789.shtml> Acesso em: 01 ago. 2012.

$>$ MACIEL, L. C. Vestindo sonhos e ideais. In: Joffily, R. (Ed.). A História da Camiseta. Rio de Janeiro: Marprint, 1988. p. 61-72.

> MAFFESOLI, M. A comunicação sem fim (teoria pós-moderna da comunicação). In: MARTINS, F. M.; SILVA, J. M. (Org.). A genealogia do virtual: comunicação, cultura e tecnologias do imaginário. Porto Alegre: Sulina, 2004. p. 20-32.

> MORAIS, M. M. Moda đt Mídia: Aspectos culturais, identitários e sociais. In: CONGRESSO BRASILEIRO DE CIÊNCIAS DA COMUNICAÇÃO, 29, 2006, Brasília. Anais... Brasília: Intercom, 2006.

> MUGGIATI, R. Relação à flor da pele. In: Joffily, R. (Ed.). A História da Camiseta. Rio de Janeiro: Marprint, 1988. p. 127-140.

> STRINATI, D. Cultura Popular: uma introdução. São Paulo: Hedra, 1999. 
Camiseta e comunicação: reflexões sobre

a indumentária nas indústrias culturais

Gabriel Baquit, bacharel em Comunicação Social - Publicidade e Propaganda pela Universidade de Fortaleza (UNIFOR). Mestrando em Design de Comunicação de Moda pela Universidade do Minho (UMINHO), Portugal.

gabrielbaquit@gmail.com 